\title{
PERCEPTIONS OF THE SERIOUSNESS OF MISPRONUNCIATIONS OF ENGLISH SPEECH SOUNDS
}

\author{
Moedjito \\ Joint Graduate School, Hyogo University of Teacher Education, Jepang \\ ITO Harumi \\ Naruto University of Education, Jepang
}

\begin{abstract}
The present study attempts to investigate Indonesian EFL teachers' and native English speakers' perceptions of mispronunciations of English sounds by Indonesian EFL learners. For this purpose, a paper-form questionnaire consisting of 32 target mispronunciations was distributed to Indonesian secondary school teachers of English and also to native English speakers. An analysis of the respondents' perceptions has discovered that 14 out of the 32 target mispronunciations are pedagogically significant in pronunciation instruction. A further analysis of the reasons for these major mispronunciations has reconfirmed the prevalence of interference of learners' native language in their English pronunciation as a major cause of mispronunciations. It has also revealed Indonesian EFL teachers' tendency to overestimate the seriousness of their learners' pronunciations. Based on these findings, the study makes suggestions for better English pronunciation teaching in Indonesia or other EFL countries.
\end{abstract}

Key words: perception, common and serious mispronunciations, pronunciation

Pronunciation is considered as one of the essential elements for the success of oral interaction (Carruthers, 1987; Celce-Murcia, Brinton, \& Goodwin, 
1996; Dalton \& Seidlhofer, 1994; Fraser, 1999; Macdonald, 2002). In Indonesian context, however, English pronunciation has rather been neglected. For example, the teaching of the English pronunciation tends to have an insufficient portion. As a result, Indonesian learners tend to make a considerable number of mistakes in pronunciation when they try to speak in English. Those mispronunciations will decrease the intelligibility of Indonesian learners' speech to a considerable degree. Needless to say, this will hamper the flow of oral communication. It is necessary, therefore, for EFL teachers to properly deal with learners' mispronunciations in their pronunciation teaching. However, very little information is available for Indonesian teachers about learners' mispronunciations, more specifically about what mispronunciations are pedagogically significant in terms of frequency and seriousness in real-life communication. Therefore, it is quite probable that Indonesian teachers will deal with their learners' mispronunciation solely on the basis of their personal intuitions.

In order to provide such missing information concerning learners' mispronunciations, there is a need to conduct a study which would explore Indonesian EFL teachers' perceptions of learners' mispronunciations and compare them with those of native English speakers' so that general tendencies and discrepancies in perceptions between the two groups can be identified. On the basis of this reasoning, the following research questions are set up: (1) What kinds of mispronunciations of English speech sounds are common and serious among Indonesian EFL learners?; (2) How do Indonesian EFL teachers' perceptions of the seriousness of mispronunciations differ from those of native English speakers'?; and (3) What kinds of mispronunciations of English sounds are pedagogically significant?

\section{METHOD}

\section{Participants}

A total of 80 respondents, 50 Indonesian EFL secondary school teachers and 30 native English speakers, voluntarily participated in the study. Of the 50 Indonesian respondents, 26 (20 males, 6 females) were senior high school teachers and 24 ( 15 males, 9 females) were junior high school teachers. These teachers had teaching experiences of various length: 7 teachers with 1-5 years of teaching experience; 11 teachers with 6-10 years of teaching experience; 18 
teachers with 11-15 years of teaching experience; and 14 teachers with more than 15 years of teaching experience. Thirty-six teachers held a bachelor's degree in English language education while 14 held a diploma certificate (all were junior high school teachers). The English native speakers (18 males, 12 females) included 3 Americans, 3 British, 1 Irish, and 23 Canadians.

\section{Instrument}

To answer questions raised in the study, a paper-form questionnaire was prepared. The questionnaire is composed of 32 target utterances which are presumed to have been produced by Indonesian EFL learners. Each utterance is composed of two sentences with a target mispronunciation in the second sentence. These 32 target mispronunciations cover 19 consonants and 13 vowelsall are segmental - which were selected on the basis of the literature review and the first author's experience as an EFL teacher at senior high schools in Indonesia. Each utterance investigated is accompanied by a pre-coded five-point Likert-scale for the judgment of the frequency of the target mispronunciations and their seriousness, from 1 ("very rare" for frequency; "not serious" for seriousness) to 5 ("very common" for frequency; "very serious" for seriousness).

The questionnaire addresses the frequency and seriousness of mispronunciations. As far as the frequency of learners' mispronunciations is concerned, we decided to focus on Indonesian EFL teachers' perception since they encounter learners' mispronunciations in their language classrooms on a daily basis. As far as the seriousness of learners' mispronunciations is concerned, we decided that Indonesian EFL teachers' perceptions should be qualified by native English speakers' perceptions. This is partly because Indonesian EFL teachers' perceptions are not always dependable due to their lack of experience of cross-cultural oral communication in English and due to their preoccupation with linguistic differences, and partly because we are interested in finding out how their perceptions of the seriousness differ from native English speakers' perceptions. The assessors' evaluation was based on their own intuitive perceptions. The details of the questionnaire are indicated in Appendix.

\section{Collection}

The questionnaire was distributed to Indonesian secondary school teachers of English and also to native English speakers. The questionnaire was designed to be anonymous and unregistered so that the respondents could give their hon- 
est opinion. Different ways were used to collect data from the participants. For the Indonesian respondents the original copy of the questionnaire was sent by e-mail attachment to the coordinator of this study in Indonesia, who printed it out, photocopied, and distributed the copies directly (in person, not by mail) to the respondents of the study. Two weeks later, the distributed questionnaire sheets were collected by the coordinator, packed, and sent back to the present researchers. For the native English speakers the copy of the questionnaire was either directly handed to the respondents living in Japan or sent by e-mail to the coordinator in Canada, who printed it out and handed the copies to the respondents. The retrieved questionnaire sheets were sorted and only the valid questionnaire sheets with complete answers were analysed.

\section{Analysis}

The tabulated scores of the frequency were averaged for each target mispronunciation and served as the basis for dichotomising the target mispronunciations into common or uncommon groups and into serious or unserious groups. Those target mispronunciations whose scores were at least the same as the median (i.e., 3.00) in terms of the frequency were classified as common and those whose scores were below the median were classified as uncommon. The same procedure was adopted for splitting the investigated mispronunciations into serious and unserious groups. Furthermore, the calculated mean scores were mapped out onto a matrix of the frequency and seriousness in order to find out which mispronunciations were the most significant for EFL learners. In addition to the mean-median comparison, the data was submitted to a Wilcoxon Mann-Whitney test to determine whether there were significant differences in the perceptions of the seriousness of the mispronunciations between the Indonesian respondents and the native English speakers.

\section{FINDINGS}

\section{Descriptive Statistics}

Table 1 presents the mean scores of all collected data on the Indonesian EFL teachers' perceptions of the seriousness of the target mispronunciations and their frequencies, the native English speakers' perceptions of their serious- 
ness, and the difference in the mean scores of the perceptions of the seriousness between the Indonesian EFL teachers and native English speakers.

Table 1. Mean scores of respondents' perceptions of the target mispronunciations

\begin{tabular}{|c|c|c|c|c|}
\hline Target Mispronunciations & Freq. $^{a}$ & $\mathrm{EFL}^{\mathrm{b}}$ & $\mathrm{NES}^{\mathrm{c}}$ & $M_{\text {diff }}{ }^{\mathrm{d}}$ \\
\hline \multicolumn{5}{|l|}{ Consonants: } \\
\hline$/ \mathrm{pe} \square \mathrm{pə} / \square / \mathrm{fe} \square$ fə/ & 2.80 & 3.18 & 3.00 & 0.18 \\
\hline $\mathrm{M} 2 / \mathrm{b} / \square / \mathrm{p} /:$ & 2.84 & 3.12 & 4.33 & $1.21^{* *}$ \\
\hline M3 $/ \mathrm{t} / \square / \square:$ & 1.84 & 1.98 & 2.33 & 0.35 \\
\hline $\mathrm{M} 4 \quad / \mathrm{d} / \square / \mathrm{t} /:$ & 3.08 & 3.16 & 2.77 & 0.39 \\
\hline /faiəmən/ $\square$ /paiəmən/ & 3.44 & 3.58 & 3.00 & $0.58^{*}$ \\
\hline$/ \square 1 \square \mathrm{vz} / \square / \square 1 \square \mathrm{ps} /$ & 3.74 & 3.80 & 3.03 & $0.77^{* *}$ \\
\hline$/ \mathrm{va} \square \mathrm{t} / \square / \mathrm{b} \partial \square \mathrm{t} /$ & 3.38 & 3.40 & 2.57 & \\
\hline$/ \mathrm{v} \square \mathrm{l} ə \mathrm{z} / \square / \mathrm{f} \square \mathrm{l} \mathrm{l} \mathrm{z} /$ & 3.22 & 3.26 & 3.07 & 0.19 \\
\hline M9 $/ \theta / \square / \mathrm{t} /:$ & 3.38 & 3.74 & 2.30 & $1.44^{* *}$ \\
\hline $\mathrm{M}^{10} / \theta / \square / \mathrm{f} /:$ & 2.42 & 2.40 & 2.33 & 0.07 \\
\hline $\mathrm{M}_{11} / \theta / \square / \mathrm{s} /:$ & 2.80 & 3.16 & 2.80 & 0.36 \\
\hline /W $\square ? \mathrm{\rho} / \square / \mathrm{w} \square \mathrm{də} /$ & 3.64 & 3.78 & 2.23 & $1.55^{* *}$ \\
\hline $\mathrm{M} 13^{/ ? / \square / \mathrm{V} /}:$ & 2.18 & 2.30 & 2.17 & 0.13 \\
\hline $\mathrm{M} 4^{/ ? / \square / \mathrm{z} /}:$ & 3.08 & 3.04 & 2.53 & $0.51^{*}$ \\
\hline$/ \square \square \square / \square / \mathrm{s} \square \square /$ & 3.54 & 3.96 & 3.47 & $0.49^{*}$ \\
\hline M16 ${ }^{\prime} \square \square / \square: \quad / \mathrm{pl} \square[$ & 3.62 & 3.64 & 1.77 & $1.87^{* *}$ \\
\hline 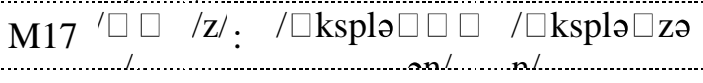 & 3.04 & 2.96 & 2.07 & $0.89^{* *}$ \\
\hline
\end{tabular}


Table 1- continued

\begin{tabular}{|c|c|c|c|c|}
\hline Target Mispronunciations & Freq. $^{\text {a }}$ & $\mathrm{EFL}^{\mathrm{b}}$ & $\mathrm{NES}^{\mathrm{c}}$ & $M_{\text {diff }}{ }^{\mathrm{d}}$ \\
\hline M18 / $\square / \square / \square /: \quad / \operatorname{tr} \square \square \boldsymbol{\partial} \square / \operatorname{tr} \square \square$ ə/ & 3.56 & 3.54 & 2.80 & $0.74^{* *}$ \\
\hline M19 /n/ $\square / \mathrm{y} /: \quad / \mathrm{s} \square \mathrm{n} / \square / \mathrm{s} \square \mathrm{y} /$ & 1.78 & 1.86 & 3.50 & $1.64^{* *}$ \\
\hline Average of Consonants & 3.02 & 3.15 & 2.74 & \\
\hline
\end{tabular}

\section{Vowels:}

\begin{tabular}{|c|c|c|c|c|}
\hline M20 /i $\square \square / \square /: \quad / p i: \square$ os $\square /$ /p $\square \square$ əS/ & 3.62 & 3.58 & 3.63 & 0.05 \\
\hline $\mathrm{M} 21 / \square / \square / \mathrm{i} \square: \quad / \square \square \mathrm{p} / \square / \square \mathrm{i} \square \mathrm{p} /$ & 3.30 & 3.56 & 3.50 & 0.06 \\
\hline M22 / $\square / \square / \square /: \quad / \mathrm{b} \square \mathrm{d} / \square \quad / \mathrm{b} \square \mathrm{d} /$ & 1.76 & 1.66 & 2.63 & $0.97^{* *}$ \\
\hline M23 /?/ $\square / \square /: \quad / b ? n d / \square / b \square$ nd/ & 3.24 & 3.40 & 2.73 & $0.67^{* *}$ \\
\hline $\mathrm{M}_{24} / ? / \square / \square: \quad / \mathrm{h} ? \mathrm{t} / \square \quad / \mathrm{h} \square \square \mathrm{t} /$ & 2.50 & 2.74 & 3.80 & $1.06^{* *}$ \\
\hline $\mathrm{M} 25 / ? / \square / \square \mathrm{s}: \quad / \mathrm{k} ? \mathrm{t} / \square \quad / \mathrm{k} \square \mathrm{t} /$ & 1.86 & 1.92 & 3.20 & $1.28^{* *}$ \\
\hline M26 /u $\square / \square /: \quad / t u \square$ ls/ $\square / t \square$ ls/ & 3.34 & 3.60 & 2.03 & $1.57^{* *}$ \\
\hline $\mathrm{M} 27 / \square / \square / \mathrm{u}: \quad / \mathrm{b} \square \mathrm{l} / \square / \mathrm{bu} \square \mathrm{l} /$ & 3.14 & 3.14 & 2.57 & $0.57^{*}$ \\
\hline $\mathrm{M} 28 / \square / \square / \square /: \quad / \mathrm{k} \square \mathrm{k} / \square / \mathrm{k} \square \mathrm{k} /$ & 2.52 & 2.58 & 4.23 & $1.65^{* *}$ \\
\hline $\mathrm{M}^{29} \mathrm{e}^{\mathrm{e}} \square / \square / \mathrm{k} \quad / \mathrm{ke} \square \mathrm{k} / \square / \mathrm{k} \square \mathrm{k} /$ & 3.00 & 3.18 & 3.57 & 0.39 \\
\hline M30 'e $\square \square / \square /: \quad$ /re $\square$ s/ $\square$ /res/ & 2.92 & 2.88 & 2.80 & 0.08 \\
\hline M31 'ə $\square \square \quad / \square /: \quad / \mathrm{k} \partial \square \mathrm{d} / \square \quad / \mathrm{k} \square \mathrm{d} /$ & 3.28 & 3.42 & 2.80 & $0.62^{*}$ \\
\hline M32 ${ }^{\prime} \square \square / \square: \quad / k \partial \square \mathrm{d} / \square / \mathrm{k} \square \square \mathrm{d} /$ & 3.34 & 3.50 & 3.07 & 0.43 \\
\hline Average of Vowels & 2.91 & 3.01 & 3.12 & \\
\hline
\end{tabular}

Note. The complete target mispronunciations are presented in Appendix.

${ }^{\mathrm{a}}$ Frequency; ${ }^{\mathrm{b}}$ The Indonesian EFL teachers; ${ }^{\mathrm{c}}$ The native English speakers; ${ }^{\mathrm{d}}$ The difference of the mean scores between EFL and NES. * $p<0.05$; ** $p<$ 0.01 


\section{Common Mispronunciations}

As mentioned previously, learners' mispronunciations are regarded as common in this paper if their mean scores are at least the same as the median (i.e., 3.00). As shown in Figure 1, out of the 32 target mispronunciations (19 consonants and 13 vowels), 20 items $(63 \%)$ are regarded as common and 12 items (37\%) as uncommon. Those 20 common mispronunciations involve 12 consonants (63\% of the target consonants) and eight vowels (67\% of the target vowels) whereas those 12 uncommon mispronunciations involve seven consonants (37\% of the target consonants) and five vowels (33\% of the target vowels).

Concerning the 20 common mispronunciations, 12 cases involve consonant mispronunciations and eight vowel mispronunciations. Of the 12 consonant mispronunciations, 11 cases involve fricatives and one case involves a plosive. Of the 11 fricative mispronunciations, five cases (M5, M6, M7, M9, and M12) feature the replacement with learners' L1 plosives, four cases (M8, M14, M16, and M17) feature the replacement with other English fricative consonants which do not exist in learners' L1, and two cases (M15 and M18) feature the replacement with other consonants which exist both in English and learners' L1 (/ $\square / \square / \mathrm{s} /$ and $/ \square / \square / \square /$ ).

The figure below shows the respondent's perception of the frequency of the mispronunciation. Of those eight common vowels, three cases (M20, M21, and M23) involve front vowels, two cases (M26 and M27) involve back vowels, and three cases (M29, M31, and M32) involve diphthongs. M23 features the replacement of a front open-mid lax vowel /? / with a front close-mid lax vowel $/ \square /$ while M20 and M21 show the interchangeable replacement of /i $\square /$ and / $\square /$. In terms of back vowels, M26 and M27 also show the interchangeable replacement of $/ \mathrm{u} \square /$ and $/ \square /$. The three cases of diphthong mispronunciation all feature the substitution with the close variants of vowels in learners' native language. 


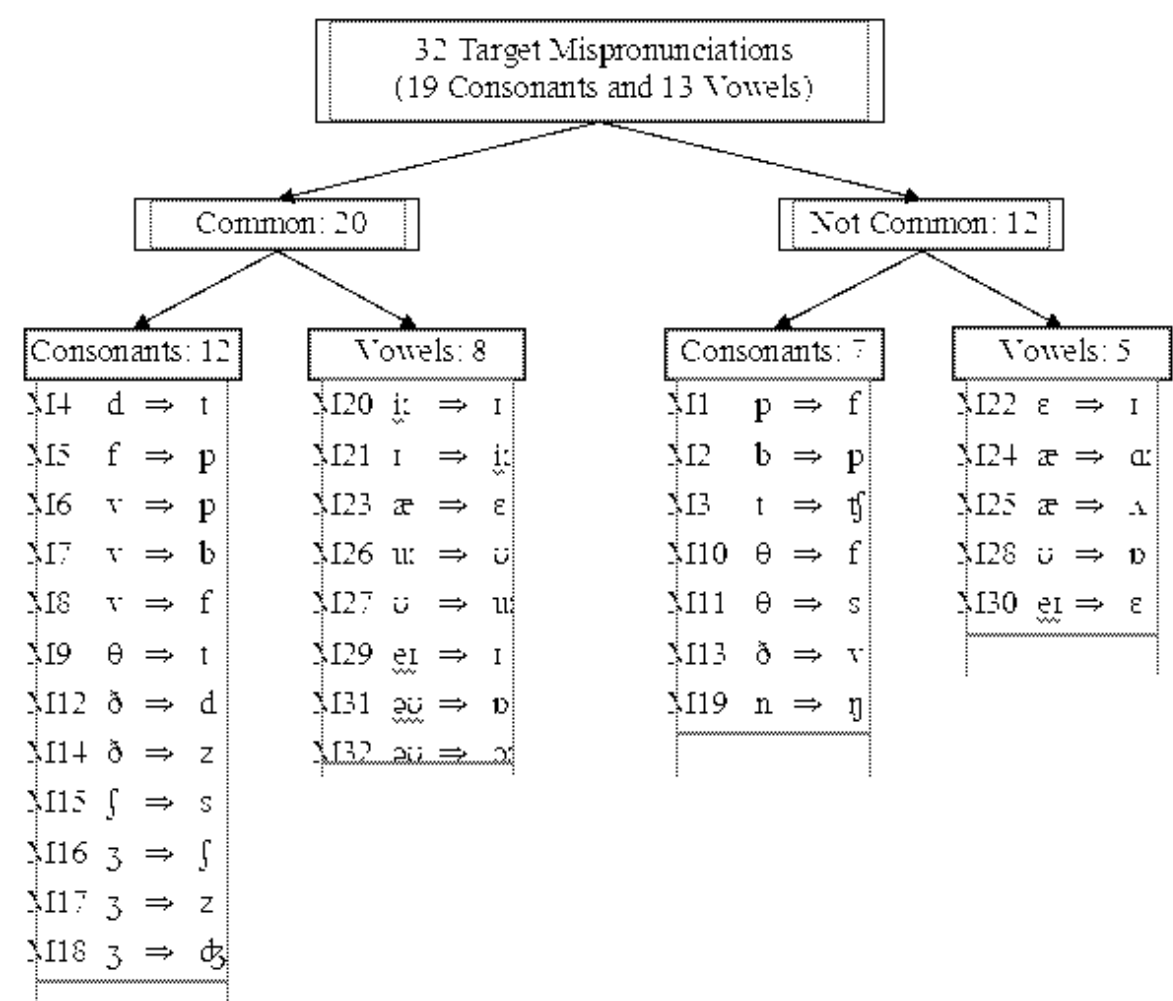

Figure 1. Indonesian respondents' perceptions of the frequency

\section{Serious Mispronunciations}

As shown in Figure 2, the Indonesian respondents viewed 22 mispronunciations $(69 \%)$ as serious and 10 mispronunciations (31\%) as unserious, whereas their native English speaker counterparts perceived only 14 mispronunciations (44\%) as serious and 18 mispronunciations (56\%) as unserious. 
32 Target Mispronunciations (19 Consonants and 13 Vowels)

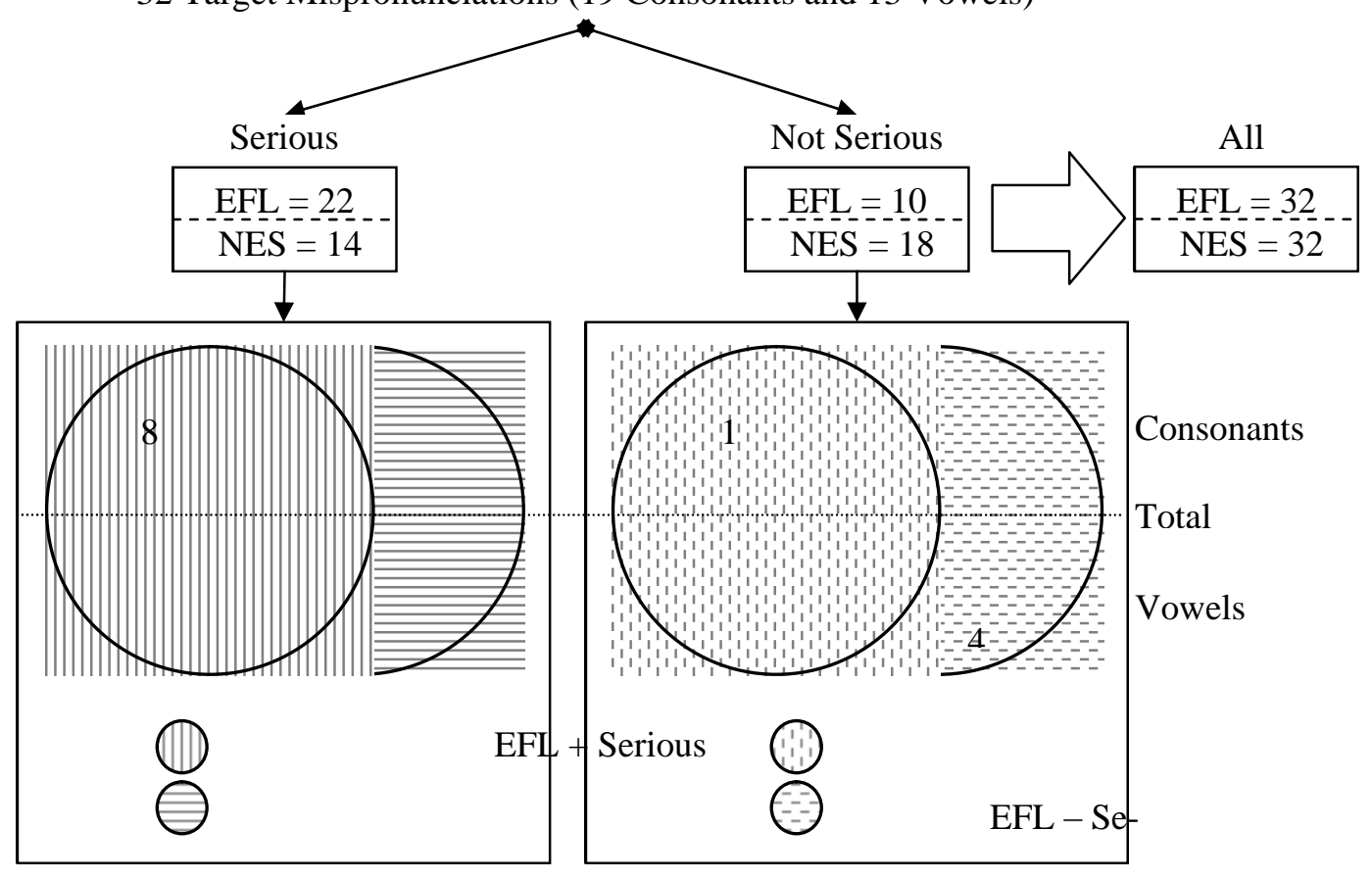

Figure 2. Respondents' perceptions of the seriousness of the target mispronunciations

Of the 22 serious mispronunciations endorsed by the Indonesian respondents, 14 cases involve consonants (74\% of the target consonants), and eight cases involve vowels (62\% of the target vowels). Of these 14 serious mispronunciations involving consonants, 11 cases feature the mispronunciations of fricatives which are replaced either with the plosive consonants in learners' L1 (e.g., $/ \mathrm{v} /$ is mispronounced either $/ \mathrm{p} /$ or $/ \mathrm{b} /$ ) or with the similar fricative sounds in their L1 (i.e., $/ \theta /$ and $/ \square /$ are mispronounced as $/ \mathrm{s} /$ ).

Of the eight serious mispronunciations involving vowels, four cases involve the interchangeable replacement of two pairs of vowels (i.e., $/ \mathrm{i} \square / \square / \square /$ in M20 and M21, and /u $\square / \square / \square /$ in M26 and M27); one case (M23) involves the replacement of the front open-mid lax vowel /? / with / $\square /$, and three cases 
(M29, M31, and M32) involve the substitution of diphthongs with the allophones of the vowels in learners' native language.

Of the 14 serious mispronunciations endorsed by the native English speakers, seven cases involve consonants (37\% of the target consonants), and seven cases involve vowels (54\% of the target vowels). Of these seven serious mispronunciations involving consonants, two cases (M1 and M2) feature the mispronunciation of plosives (i.e., /p/ $\square / \mathrm{f} / ; / \mathrm{b} / \square / \mathrm{p} /$ ), four cases (M5, M6, M8, and M15) feature the mispronunciation of fricatives (i.e., /f/ $\square / \mathrm{p} / ; / \mathrm{v} / \square / \mathrm{p} /$; /v/ $\square / \mathrm{f} /$; $/ \square / \square / \mathrm{s} /$ ), and one case (M19) features the mispronunciation of a nasal (i.e., $/ \mathrm{n} / \square / \mathrm{h} /$ ). Of the seven serious mispronunciations involving vowels, four cases (M20, M21, M24 and M25) feature the mispronunciation of front vowels (i.e., /i $\square / \square / \square /$; / $\square / \square / \mathrm{i} \square /$; /?/ $\square / \square \square /$; / / $\square / \square /$ ), one case (M28) features the mispronunciation of a back vowel ((i.e., $/ \square / \square / \square /$ ), and two cases (M29 and M31) feature the mispronunciation of diphthongs (i.e., /e $\square / \square / \square /$; /ə $\square / \square / \square \square /$ ).

\section{Categorisation of Mispronunciations}

As shown in Figure 3, a combination of the English native speakers' perceptions of the seriousness of mispronunciations and the Indonesian teachers' perceptions of their frequency has led to the classification of the 32 target mispronunciations into the following four groups:

a. Group 1: eight mispronunciations (25\% of the 32 target mispronunciations) which are serious and common, involving four consonants (M5 [/f/ $\square / \mathrm{p} /]$; M6 $[/ \mathrm{v} / \square / \mathrm{p} /] ; \quad$ M8 $[/ \mathrm{v} / \square / \mathrm{f} /] ; \quad$ M15 $[/ \square / \square / \mathrm{s} /]$ ) and four vowels (M20

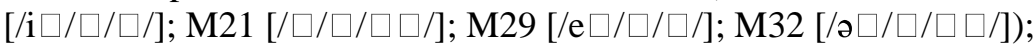

b. Groups 2: six mispronunciations (19\% of the 32 target mispronunciations) which are serious but uncommon, involving three consonants (M1 $[/ \mathrm{p} / \square / \mathrm{f} /] ; \mathrm{M} 2[/ \mathrm{b} / \square / \mathrm{p} /] ; \mathrm{M} 3$

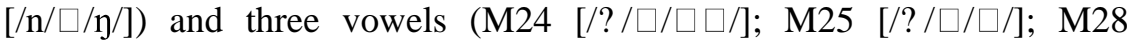
$[/ \square / \square / \square /]) ;$ 


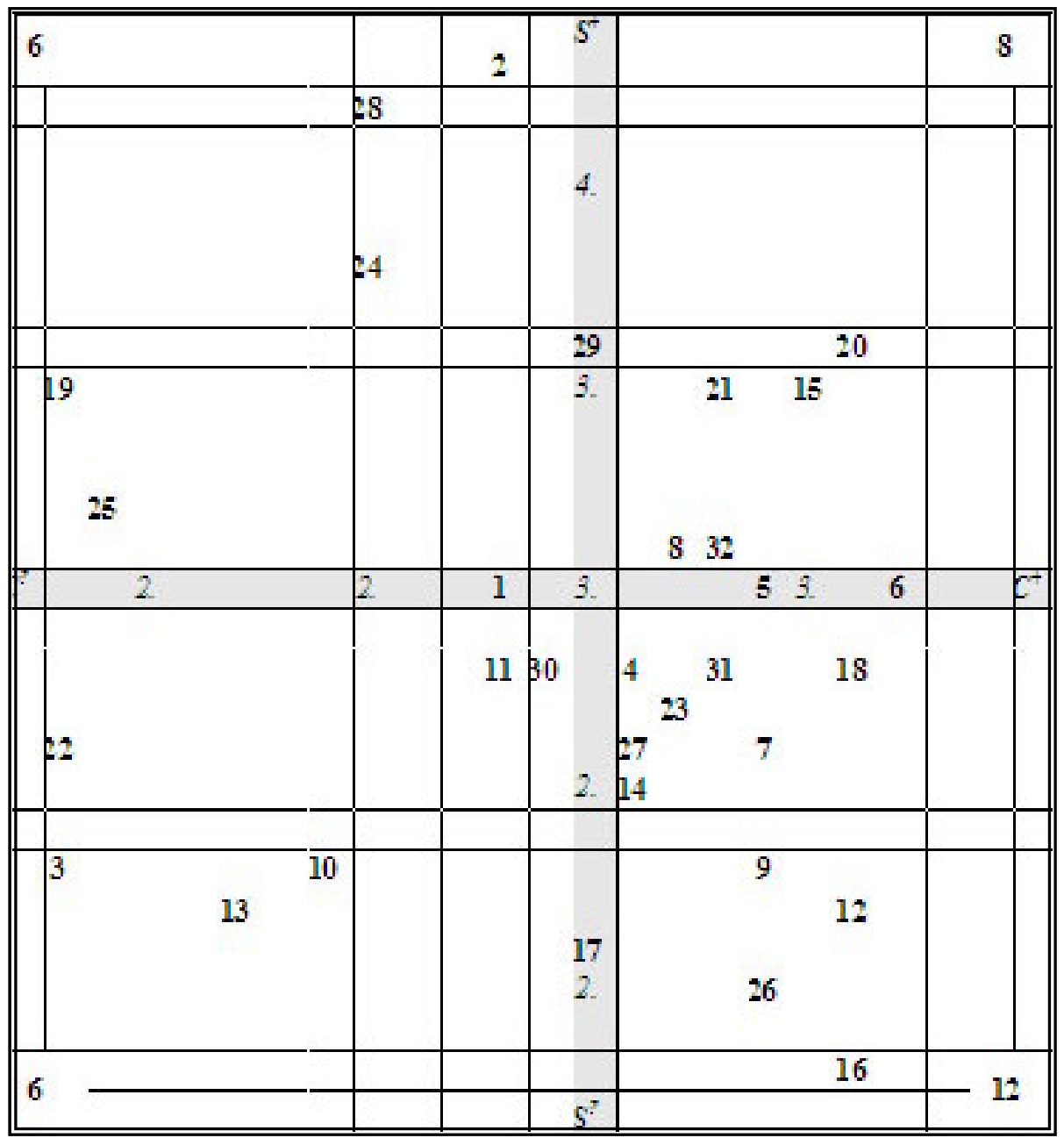

Note. $\boldsymbol{C}^{-}=$uncommon; $\boldsymbol{C}^{+}=$common; $\boldsymbol{S}^{-}=$unserious; $\boldsymbol{S}^{+}=$serious

Figure 3. Mean-matrix of the Indonesian respondents' perceptions of the frequency and native English speakers' perceptions of the seriousness

c. Group 3: 12 mispronunciations (37\% of the 32 target mispronunciations) which are unserious but common, involving eight consonants (M4 
$[/ \mathrm{d} / \square / \mathrm{t} /] ; \mathrm{M} 7[/ \mathrm{v} / \square / \mathrm{b} /] ; \mathrm{M} 9[/ \theta / \square / \mathrm{t} /] ; \mathrm{M} 12[/ ? / \square / \mathrm{d} /] ; \mathrm{M} 14$ [/?/ $\square / \mathrm{z} /] ;$ M16 $[/ \square / \square / \square /] ;$ M17 $[/ \square / \square / \mathrm{z} /] ;$ M18 $[/ \square / \square / \square /]$ ) and four vowels (M23

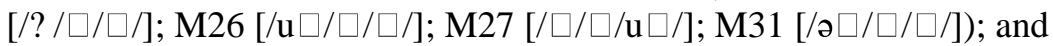

d. Group 4 : six mispronunciations (19\% of the 32 target mispronunciations) which are unserious and uncommon, involving four consonants (M3

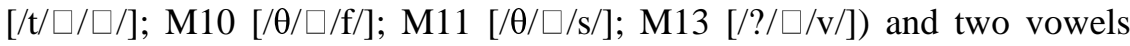

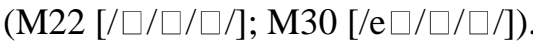

\section{Significant Difference in the Perceptions of the Seriousness}

As presented in Table 1, a Wilcoxon Mann Whitney test has disclosed that there exists a significant difference in the perceptions of the seriousness between the Indonesian EFL teachers and the native English speakers for 20 target mispronunciations (63\% of the 32 target mispronunciations).

Of these 20 mispronunciations, four mispronunciations (all are consonants) were perceived as serious by both groups of the respondents; 10 mispronunciations (6 consonants and 4 vowels) were perceived as serious by EFL teachers alone, four mispronunciations ( 1 consonant and 3 vowels) were perceived as serious by native English speakers alone, and two mispronunciations ( 1 consonant and 1 vowel) were rated as unserious by both groups of the respondents. Of those four mispronunciations which were rated as serious by both groups, there was only one mispronunciation (i.e., /b/ $\square / \mathrm{p} /$ ) whose mean score of the native English speakers was larger than that of the Indonesian EFL teachers.

\section{DISCUSSION}

The study was designed to explore and compare the Indonesian EFL teachers' and native English speakers' perceptions of the mispronunciations of English sounds focusing on the frequency of those mispronunciations and their seriousness, the significant differences in the perceptions between the Indonesian EFL teachers and the native English speakers, and the pedagogically most significant mispronunciations in EFL classrooms.

As far as the frequency of mispronunciations is concerned, the result of the study has indicated that 20 mispronunciations (12 consonants and 8 vowels) were perceived as common by the Indonesian EFL teachers. This implies that Indonesian EFL learners are still facing a problem with pronunciation although 
this indicator inarguably needs to be qualified with the seriousness of the common mispronunciations.

Concerning serious mispronunciations, there is a tendency for Indonesian EFL teachers to overestimate the seriousness of learners' mispronunciations. One possible reason for this overestimation is that Indonesian EFL teachers lack experiences of interacting with English speaking people. As a result, they do not feel confident of accessing the seriousness of the target mispronunciations. Another reason is that Indonesian EFL teachers tend to perceive the seriousness of learners' mispronunciations on the basis of their limited knowledge about English phonology mainly obtained from lectures and phonology books which are usually linguistically oriented with little reference to problems Indonesian EFL learners are to encounter in real communicative situations. Thus, actual experience of oral communication in English is crucial for EFL teachers so that they can decide what aspects of English pronunciation are more important and have greater pedagogical significance for EFL learners.

Apart from the discussion of which mispronunciations are common and serious, the result of the study has also discovered that there are 14 mispronunciations - those which are common and serious/unserious - which are pedagogically significant in the teaching of English pronunciation. These 14 mispronunciations-seven consonants and seven vowels-require more serious attention in pronunciation teaching in Indonesian classrooms (cf. Kashiwagi, Snyder, \& Craig, 2006; Rajadurai, 2007). A careful analysis of these 14 mispronunciations has revealed that they are mostly caused by the following three major factors.

\section{Absence of English speech sounds in learners' L1}

Although some English speech sounds do not exist in learners' L1, some learners can pronounce these sounds due to the prior learning of other languages such as Arabic or another local language-for example, Buginese (the language spoken by people who live in the province of South Sulawesi, Indonesia). In the case of the mispronunciation /v/ $\square / f /$ (M8), for example, many Indonesian EFL learners, especially those who are Moslems, can produce the voiceless labiodental fricative /f/ properly because of the Arabic influence. However, this language transfer is not always put in the right place so that many learners do over-generalisation frequently, such as /p/ $\square / \mathrm{f} /$ (M1). 


\section{Different distribution of the same sounds in English and learners' $L 1$}

The English phoneme /b/ as in M2, for example, can exist in final, middle, or initial positions while the Indonesian phoneme /b/ never exists in the final position. According to the writing system of the Indonesian language, the letter $\langle\mathrm{b}\rangle$ can exist in the final position but its pronunciation is always devoiced as $/ \mathrm{b} \square /$. Even in many cases, the final phoneme /b/ is usually pronounced as the voiceless bilabial plosive $/ \mathrm{p} /$, such as $/ \mathrm{kr}$ ?b/ which is mispronounced as $/ \mathrm{kr}$ ? $\mathrm{p} /$.

\section{Different categorisation of sounds in English and learners' L1}

In terms of vowels, Gimson (2001) asserted that "most foreign learners will have trouble attaining the vowel system of any variety of English, including RP" (p. 103). This assertion is reasonably compatible with the finding of the present study. Unlike English which has many vowels (up to 20 vowels and diphthongs), either Indonesian learners' native language or the Indonesian language mostly has only five vowels with their allophones: /a/ with [a] and [ $\square$ ]; /i/ with [ $\square]$ and [i $\square$ ]; /u/ with $[\square]$ and [u $\square$ ]; /e/ with [e], [ $\square]$, and [ə]; and /o/ with $[o]$ and $[\square]$. For this reason, many Indonesian students, for example, are facing a problem to differentiate the sound $[\mathrm{i} \square]$ as in $/ \square \mathrm{i} \square \mathrm{p} /$ for 'sheep' from the sound $[\square]$ as in $/ \square \square \mathrm{p} /$ for 'ship' because these sounds [i $\square]$ and [ $\square]$ are the allophones of the Indonesian phoneme /i/. Unfortunately, this difficulty becomes more complicated because of English spelling which does not correspond to the English sounds while Indonesian spelling and its sound always coincide. In the Indonesian language, for example, the letter $\langle\mathrm{a}\rangle$ is always pronounced as the primary cardinal [a] or $[\square]$.

Thus the findings of the study are consonant with recent research findings that the absence of English sounds in learners' L1 and the different distribution of the same/similar sounds in English and learners' L1 are the main reasons for difficulty in pronunciation for EFL learners (Carruthers, 1987; Moedjito, 2006; Ohata, 2004). Based on these findings, we have come to a conclusion that learners' native language is still an active agent for the mispronunciation of English sounds through phonological negative transfer. This finding is partly consistent with Lado (1957)'s contrastive analysis hypothesis (CAH) which assumes that it would be easy for L2 learners if the elements of L2 were similar to those of their L1, and it would be difficult for them if those elements were different from those of their L1. This suggests that CAH is still useful as an explanatory tool to clarify learners' mispronunciations. 


\section{CONCLUSIONS AND SUGGESTIONS}

Although our study has revealed several interesting facts about mispronunciations by Indonesian EFL learners, we must point out that the study has several limitations. Firstly, it investigated only the segmental features of pronunciations with no reference to suprasegmental features such as intonations and sentence stresses. Secondly, the participants of the study were limited to the Indonesian EFL teachers and the native English speakers who were chosen on an opportunistic basis, not on a random basis. Thirdly, the data of the study was collected by means of a paper-form questionnaire dealing with the 32 target mispronunciations which in turn were compiled on the basis of the first author's self-experience as an EFL teacher at Indonesian senior high schools. Fourthly, only native speakers' perceptions were used as reference points for comparison with Indonesian EFL teachers' perceptions. Considering the fact that English is now used as a global language, it may be necessary to include non-native speakers who regularly use English as a second language.

While acknowledging these limitations of the study, we believe that the findings of the study can be used as the points of reference for better English pronunciation teaching in EFL classrooms. The study also suggests that Indonesian EFL teachers should review their own perceptions of the seriousness of mispronunciations of English sounds. More attention should be paid to the significant mispronunciations through explicit instruction such as specific explanations and demonstrations concerning the differences in two languages, and production drills and sound discrimination exercises focused on these differences.

As generally accepted, pronunciation should focus not only on segmental features, but also on suprasegmental features. The next study should be extended to those suprasegmental features such as rhythm, intonation, stress, and adjustments in connected speech. Furthermore, because the participants of the study were limited to the Indonesian EFL teachers and native English speakers, ESL speakers should be included as evaluators of the seriousness of mispronunciations in the next study if we take into consideration the fact that the interaction between non-native speakers (NNS-NNS communication) has steadily been increasing (Jenkins, 2000, McKay, 2002; Walker, 2001). As long as we teach English as a global language, our goal should be global intelligibility, 
not intelligibility comfortable only to native speakers of English. The present study is a step toward this final goal.

\section{REFERENCES}

Carruthers, R. 1987. Teaching pronunciation. In Long, M. H. \& Richards, J. C. (Eds.), Methodology in TESOL (pp. 35-44). New York: Newbury House Publishers.

Celce-Murcia, M., Brinton, D. M., \& Goodwin, J. M. 1996. Teaching pronunciation: A reference for teachers of English to speakers of other languages. Cambridge: Cambridge University Press.

Crystal, D. 1997. English as a global language. Cambridge: Cambridge University Press.

Dalton, C., \& Seidlhofer, B. 1994. Pronunciation. Oxford: Oxford University Press.

Departemen Pendidikan dan Kebudayaan RI. 1994. Gari-garis besar program pengajaran mata pelajaran bahasa Inggris sekolah lanjutan tingkat pertama. Jakarta: Balai Pustaka.

Departemen Pendidikan Nasional RI. 2004. Kurikulum dan hasil belajar (kompetensi dasar) mata pelajaran bahasa Inggris sekolah lanjutan tingkat pertama. Jakarta: Pusat Kurikulum Balitbang Depdiknas.

Fraser, H. 1999. ESL pronunciation teaching: Could it be more effective? Australian Language Matters, 7(4): 7-8.

Gimson, A. C. 2001. Gimson's pronunciation of English (6th ed.). London: Arnold.

Jenkins, J. 2000. The phonology of English as an international language. Oxford: Oxford University Press.

Jenkins, J. n.d. Global English. Retrieved August 31, 2006, from htttp://_www.teaching english.org.uk/think/pron/global_english.shtml

Kashiwagi, A., Snyder, M., \& Craig, J. 2006. Suprasegmentals vs. segmentals: NNS phonological errors leading to actual miscommunication. JACET Bulletin, 43: 43-57. 
Macdonald, S. 2002. Pronunciation-views and practices of reluctant teachers. Prospect, 17(3). Retrieved April 3, 2004, from http://WwW.ncelthimq.edu.au/prospect/17/pros17 3smac.asp

McKay, S. L. 2002. Teaching English as an international language. Oxford: Oxford University Press.

Moedjito. 2006. A study on perceptions of pronunciation among EFL teachers and students in Indonesia. Unpublished master's thesis, Naruto University of Education.

Ohata, K. 2004. Phonological differences between Japanese and English: Several potentially problematic areas of pronunciation for Japanese ESL/EFL learners. Asian EFL Journal, 6(4): 1-19.

Rajadurai, J. 2007. Intelligible pronunciation: Focus on the proficient L2 speakers. The Journal of Asia TEFL, 4(1): 1-25.

Walker, R. 2001. Pronunciation for international intelligibility. English Teaching Professional, 21. Retrieved May 24, 2005, from http://www3.telus.net/linguisticsissuest, internationallyintelligibility.html

Widdowson, H. G. 2003. Defining issues in English language teaching. Oxford: Oxford University Press. 


\section{APPENDIX \\ The Questionnaire on the Mispronunciations of English Sounds}

\section{Before You Start}

a. In the following examples, only the mispronounced part of the target word is italicised while the original form of the target word is maintained as much as possible. The target word itself is presented in the parenthesis.

b. The phonetic transcriptions are given on the basis of Longman Pronunciation Dictionary by J. C. Wells (2000).

Suppose you are talking with a foreigner in English. You will come across the following examples of mispronunciation of English sounds. Please indicate how serious you will find those examples of mispronunciation by choosing the referent number $(1-5)$ which indicates your perception of seriousness.

$$
\begin{aligned}
\text { Very serious } & =5 \\
\text { Serious } & =4 \\
\text { Somewhat serious } & =3 \\
\text { Hardly serious } & =2 \\
\text { Not serious } & =1
\end{aligned}
$$

1. $/ \mathrm{p} / \square / \mathrm{f} /$ You know tomorrow is the deadline. Have you finished your fafer (paper)?

/fe $\square$ fə/ /pe $\square$ pə/

2. $/ \mathrm{p} / \square / \mathrm{b} / \quad$ You like seafood very much, don't you? Will you have some crap (crab)?

$/ \mathrm{kr} ? \mathrm{p} / \mathrm{kr} ? \mathrm{~b} /$

3. $\quad / \square / \square / \mathrm{t} / \mathrm{P} \quad$ Please make yourself at home. Would you like some

chea (tea)?

$/ \square \mathrm{i} \square / / \mathrm{ti} \square /$

(Appendix continues)

Appendix-continued 
4. $/ \mathrm{d} / \square / \mathrm{t} / \quad$ Now, let's start fishing. Where is my rot (rod)?

$$
/ \mathrm{r} \square \mathrm{t} / / \mathrm{r} \square \mathrm{d} /
$$

5. $\quad / \mathrm{f} / \square / \mathrm{p} / \quad$ I'm proud of my father. He's a pireman (fireman).

$/ \mathrm{pa} \square$ əmən//fa $\square$ əmən/

6. $\quad / \mathrm{v} / \square / \mathrm{p} / \quad$ It's very cold outside. Don't forget to put on your glupes (gloves).

$/ \square 1 \square \mathrm{ps} / / \square 1 \square \mathrm{vz} /$

7. $/ \mathrm{v} / \square / \mathrm{b} / \quad$ Who won the election? Do you know the result of the bote (vote)?

/bə $\square \mathrm{t} / / \mathrm{va} \square \mathrm{t} /$

8. /v/ $\square / f / \quad$ I don't like staying in hotels. Are there any fillas (villas) around here?

/f $\square$ ləz/ /v $\square$ ləz/

9. $/ \theta / \square / \mathrm{t} / \mathrm{I}$ don't need too many volunteers. Tree (Three) is enough. /tri $\square /$ / ri $\square /$

10. / / / $\square / f / \quad$ Nancy has been in hospital for three months. Now, she looks very pale and fin (thin). $/ \mathrm{f} \square \mathrm{n} / / \theta \square \mathrm{n} /$

(Appendix continues)

Appendix-continued

11. $/ \theta / \square / \mathrm{s} /$ Let me see your bad tooth. Open your mouse (mouth), please. 
$/ \mathrm{ma} \square \mathrm{s} / / \mathrm{ma} \square \theta /$

12. $/$ ? / $\square / \mathrm{d} / \quad$ Did you enjoy your holiday? How was the weader (weather)?

$/ \mathrm{w} \square \mathrm{d} \partial / / \mathrm{w} \square ? \mathrm{\rho} /$

13. /?/ $\square / \mathrm{v} / \mathrm{Hi}$, Beth, this is Tom. May I speak to your bruver (brother)?

/br $\square$ və/ /br $\square$ ?ə/

14. /?/ $\square / z / \quad$ Thanks a lot. It's the finest leazer (leather) jacket I've ever seen. $\quad / 1 \square \mathrm{zə} / \quad / 1 \square$ ?ə/

15. $/ \square / \square / \mathrm{s} / \quad$ It's fine today. Why don't we go to the sore (shore)? /s $\square \square /$

$/ \square \square \square /$

16. $/ \square / \quad \square$ Don't mention it. It was my pleashure (pleasure). $/ \square /$ $/ \mathrm{pl} \square \square \mathrm{a} /$ $/ \mathrm{pl} \square \square \mathrm{\partial} /$

17. $/ \square / \square / z / \quad$ She lit the gas range. Then there was a loud explozen (explosion).

/ $\square \mathrm{kspl} ə \square \mathrm{zən} / / \square \mathrm{kspl} ə \square \square$ on/

(Appendix continues)

Appendix-continued

18. $/ \square / \square / \square / \quad$ I really like this museum. It has many art treadgures (treasures).

$/ \operatorname{tr} \square \square \partial z /$

$/ \operatorname{tr} \square \square \partial z /$ 
90 TEFLIN Journal, Volume 19, Number 1, February 2008

19. $/ \mathrm{n} / \square / \mathrm{n} / \quad$ She is very lucky to marry John. He is the only song (son) of a rich family.

$/ \mathrm{s} \square \mathrm{y} / / \mathrm{s} \square \mathrm{n} /$

20. /i $\square / \quad \square \quad$ Which kind of fruit do you like? I myself like pitches $/ \square / \quad$ (peaches).

$/ \mathrm{p} \square \square$ əs/ /pi $\square \square$ as/

21. $/ \square / \quad \square \quad$ Sorry, all the air tickets were sold out! We have to go /i $\square / \quad$ by sheep (ship).

$$
/ \square \mathrm{i} \square \mathrm{p} / \quad / \square \square \mathrm{p} /
$$

22. $/ \square / \quad \square \quad$ I had a very bad flu yesterday. I was in bid (bed) by $/ \square / \quad$ nine. $\quad / \mathrm{b} \square \mathrm{d} / / \mathrm{b} \square \mathrm{d} /$

23. /? / $\square$ I've heard you're a good guitarist. Why don't you $/ \square / \quad$ join our bend (band)?

$/ \mathrm{b} \square \mathrm{nd} / / \mathrm{b}$ ?nd/

(Appendix continues)

Appendix-continued

24. /? / $\square$ The meeting is very formal. So, please take off your / $\square \square / \quad$ heart (hat).

$/ \mathrm{ha} \square \mathrm{t} / / \mathrm{h}$ ?t/

25. /? / $\square$ We like animals. We used to keep two dogs and a cut $/ \square / \quad$ (cat). 
$/ \mathrm{k} \square \mathrm{t} / / \mathrm{k} ? \mathrm{t} /$

26. $/ \mathrm{u} \square /$

/ $\square /$

$\square$ I want to fix my bicycle. May I borrow your t $u$ ls

(tools)?

$/ \mathrm{t} \square \mathrm{lz} /$

$/ \mathrm{tu} \square \mathrm{lz} /$

27. $/ \square / \square / \mathrm{u} \square /$ He's a nice farmer. He can control his booll (bull) very well.

/bu $\square \mathrm{l} /$

$/ \mathrm{b} \square \mathrm{l} /$

28. $/ \square / \quad \square \quad$ Anton is going to prepare the dinner tonight. He is a

$/ \square / \quad$ good cock (cook).

$/ \mathrm{k} \square \mathrm{k} / \mathrm{k} \square \mathrm{k} /$

29. $/ \mathrm{e} \square /$

$/ \square /$

I like sweets a lot. Where can we eat the best kick

(cake) here?

$/ \mathrm{k} \square \mathrm{k} / \mathrm{ke} \square \mathrm{k} /$

(Appendix continues)

\section{Appendix-continued}

30. /e $\square / \quad \square \quad$ I am completely exhausted. That was a really tough $/ \square /$ ress (race).

$/ \mathrm{r} \square \mathrm{s} / / \mathrm{re} \square \mathrm{s} /$

31. /ə $\square / \square / \square /$ My brother used to be in the navy. So, he can use the Morse cod (code).

$/ \mathrm{k} \square \mathrm{d} / / \mathrm{k} \boldsymbol{} \square \mathrm{d} /$ 
92 TEFLIN Journal, Volume 19, Number 1, February 2008

32. $/ \mathrm{a} \square / \quad \sqsubset$ You look gorgeous today. Where did you get this $/ \square \square / \quad$ nice caught (coat)?

$$
/ \mathrm{k} \square \square \mathrm{t} / \quad / \mathrm{k} \partial \square \mathrm{t} /
$$

